\title{
Optimalisasi Pengelolaan Surat Keputusan Pada Fakultas Teknik Universitas Negeri Gorontalo
}

\author{
Abdulrahmat E Ahmad 1), Mohammad Hidayat Koniyo 2), Lillyan Hadjaratie ${ }^{3)}$ \\ 1),2),3) Jurusan Teknik Informatika, Fakultas Teknik, Universitas Negeri Gorontalo \\ e-mail : ahmadrahmat14@gmail.com
}

\begin{abstract}
Abstrak
Pengelolaan surat keputusan di Fakultas Teknik Universitas Negeri Gorontalo saat ini masih mengalami beberapa kendala, mulai dari keterlambatan dalam menanggapi proses pengusulan surat keputusan, proses pembuatan surat yang memakan waktu sangat lama, hingga pendistribusian surat tidak sampai kepada yang mengusulkan. Penelitian ini bertujuan untuk mengoptimalkan pengelolaan surat keputusan dengan menggunakan sistem informasi dan teknologi web service untuk pertukaran data antar sistem yang berhubungan. Metode penelitian yang digunakan yaitu metode pengembangan sistem Prototype. Hasil penelitian menunjukan bahwa dengan sistem informasi manajemen surat keputusan berbasis web service, pengelolaan surat keputusan lebih optimal. Sistem ini dapat mengolah nomor surat keputusan secara otomatis dan dapat memonitoring pengusulan, pembuatan dan disposisi surat. Penggunaan sistem informasi manajemen surat keputusan memudahkan pengelolaan surat keputusan yang ada dilingkungan Fakultas Teknik Universitas Negeri Gorontalo.
\end{abstract}

Kata Kunci: Pengelolaan Surat, Web Service, Prototype, Optimalisasi.

\begin{abstract}
Management of decree in Faculty of Engineering, State University of Gorontalo is currently still experiencing several obstacles such as lateness in responding proposal, process of the decree, making process of the decree which takes very long time and distribution of decree that does not go to the proposer. This research aims to optimize management of decree by using information system and web service technology for data exchange among connected system. This research uses Prototype system development method. Research finding reveals that information system of web service-based decree makes the management of decree more optimum. The system can process number of decree automatically and can monitor its proposal, making and disposition. Utilization of this information system eases management of decree in Faculty of Engineering, State University of Gorontalo.
\end{abstract}

Keywords: Letter Management, Web Service, Prototype, Optimization.

Diterima Februari 2018

\section{Pendahuluan}

\section{Latar Belakang}

Surat keputusan adalah surat yang berisi suatu keputusan yang dibuat oleh pimpinan suatu organisasi atau lembaga pemerintahan berkaitan dengan kebijakan organisasi atau lembaga tersebut. Di Fakultas Teknik Universitas Negeri Gorontalo, surat keputusan merupakan aspek yang sangat penting dalam pemberian informasi dalam lingkungan fakultas, terutama pada Bagian Administrasi Kepegawaian. Informasi yang diberikan pada surat keputusan bermacam-macam diantaranya mengenai surat keputusan pembimbing skripsi dan kerja praktek, surat keputusan 
penguji skripsi dan kerja praktek, surat keputusan penasehat akademik, dan sebagainya.

Manajemen surat keputusan yang ada di Fakultas Teknik Universitas Negeri Gorontalo sendiri masih mengalami beberapa kendala. Kendala yang terjadi mulai dari keterlambatan dalam menanggapi proses pengusulan surat keputusan, begitu juga dalam proses pembuatan surat yang memakan waktu yang sangat lama, hingga pendistribusian surat tidak sampai kepada yang mengusulkan. Hal ini mengakibatkan beberapa masalah, masalah yang sering ditemui yaitu Dosen menguji skripsi dan kerja praktek tanpa adanya surat keputusan penguji terlebih dahulu. Masalah lainnya yaitu Dosen melakukan pembimbingan skripsi dan kerja praktek tanpa adanya sudat keputusan pembimbing terlebih dahulu. Tentu hal ini tidak sesuai dengan Standar Operasional Prosedur (SOP) yang berjalan di Fakultas Teknik Universitas Negeri Gorontalo.

Berdasarkan permasalahan diatas, maka dibutuhkan suatu sistem informasi dengan menerapkan teknologi web service untuk pertukaran data antar sistem yang berhubungan, dengan adanya sistem ini maka urusan terkait surat keputusan lebih terstruktur dengan baik, dimana dalam menanggapi pengusulan surat keputusan dengan cepat, dapat memberikan nomor surat keputusan secara otomatis sehingga tidak lagi membutuhkan proses yang lama dalam pembuatan surat keputusan, kemudian dapat memantau pendistribusian surat keputusan sehingga dari awal pengusulan surat, proses pembuatan, sampai surat keputusan diterbitkan dan didistribusi akan terlihat jelas prosesnya. Dengan adanya sistem ini, diharapkan mampu mengoptimalkan pengelolaan surat keputusan yang berjalan sehingga lebih sesuai dengan Standar Operasional Prosedur (SOP) yang berlaku di Fakultas Teknik Universitas Negeri Gorontalo.

\section{Rumusan Masalah}

Bagaimana mengoptimalkan pengelolaan surat keputusan dengan menggunakan sistem informasi dan teknologi web service?

\section{Ruang Lingkup}

Ruang lingkup penelitian yaitu :

1. Sistem menerima usulan penerbitan surat keputusan dari tiap jurusan.

2. Sistem dapat memonitoring distribusi surat keputusan mulai dari proses pengusulan, pembuatan, sampai proses penerbitan surat.

3. Terdapat proses verifikasi dan validasi secara berjenjang dalam proses penerbitan surat keputusan. 
4. Lampiran surat keputusan yang dihasilkan oleh sistem belum dapat membedakan penggunaan posisi kertas portrait dan landscape secara bersamaan.

\section{Manfaat Penelitian}

Adapun manfaat penelitian yang dapat diperoleh yaitu :

a. Memudahkan Sub Bagian Pendidikan dan Pengajaran, Sub Bagian Keuangan, Sub Bagian Kemahasiswaan dalam mengontrol manajemen surat keputusan yang ada dilingkungan Fakultas Teknik Universitas Negeri Gorontalo.

b. Membantu serta memudahkan dosen dan mahasiswa yang membutuhkan pembuatan surat keputusan.

c. Memudahkan proses pertukaran data antar sistem informasi yang terkait.

\section{Studi Pustaka}

Surat merupakan sarana komunikasi dalam bentuk tulisan, apapun medianya. Tata persuratan merupakan tahap penciptaan dalam daur hidup Arsip. Kegiatan tata persuratan menyangkut materi yang lingkupnya esensial dalam komunikasi kedinasan yang meliputi penentuan jenis surat, sifat, format surat yang menampung bentuk redaksional serta penggunaan sarana pengamanan surat, serta kewenangan penandatanganan. Pembakuan elemen-eleman dalam tata peraturan tersebut apabila dilaksanakan dengan benar dan konsisten maka efisiensi dan efektifitas dalam rangka menciptakan tata persuratan yang berdaya guna dan berhasil guna dapat diwujudkan. (Anggraini, 2008 : 13).

Informasi merupakan hasil olahan data, di mana data tersebut sudah diproses dan diinterpretasikan menjadi sesuatu yang bermakna untuk pengambilan keputusan. (Kusrini, $2007:$ 4).

Web service merupakan suatu komponen software yang merupakan selfcontaining, aplikasi modular self- describing yang dapat dipublikasikan, dialokasikan, dan dilaksanakan pada web (Wahli, dkk dalam Deviana, 2007). Web service adalah teknologi yang mengubah kemampuan internet dengan menambahkan kemampuan transactional web, yaitu kemampuan web untuk saling berkomunikasi dengan pola program-to-program (P2P). Fokus web selama ini didominasi oleh komunikasi program-to-user dengan interaksi business toconsumer (B2C), sedangkan transactional web akan didominasi oleh program toprogram dengan interaksi business-to-business (Gottschalk dalam Deviana, 2007).

REST adalah salah satu jenis web service yang menerapkan konsep perpindahan antar state. State disini dapat digambarkan seperti jika browser meminta suatu halaman web, maka server akan mengirimkan state halaman web yang sekarang ke browser (Tidwell, 2001). Framework sebagaimana arti dalam Bahasa 
Indonesia yaitu kerangka kerja, dapat diartikan sebagai kumpulan dari library (class) yang bisa diturunkan, atau bisa langsung dipakai fungsinya oleh modul - modul yang akan dikembangkan (Wardana, 2012).

Sedangkan pengertian Codelgniter adalah aplikasi open source yang berupa framework dengan model MVC (Model, View, Controller) untuk membangun website dinamis. Dengan menggunakan PHP Codelgniter akan memudahkan developer untuk membuat aplikasi web dengan cepat dan mudah dibandingkan dengan membuat dari awal (Wardana, 2012).

MVC (Model View Controller) adalah pendekatan perangkat lunak yang memisahkan aplikasi logika dari presentasi. Ini digunakan untuk meminimalkan script dari hamalan - halaman web sejak script presentasi (HTML, CSS, Javascript, dII) dipisahkan dari PHP scripting, istilah umum yang familiar adalah menghindari terjadinya spagetti code.

Berikut adalah konsep dari MVC :

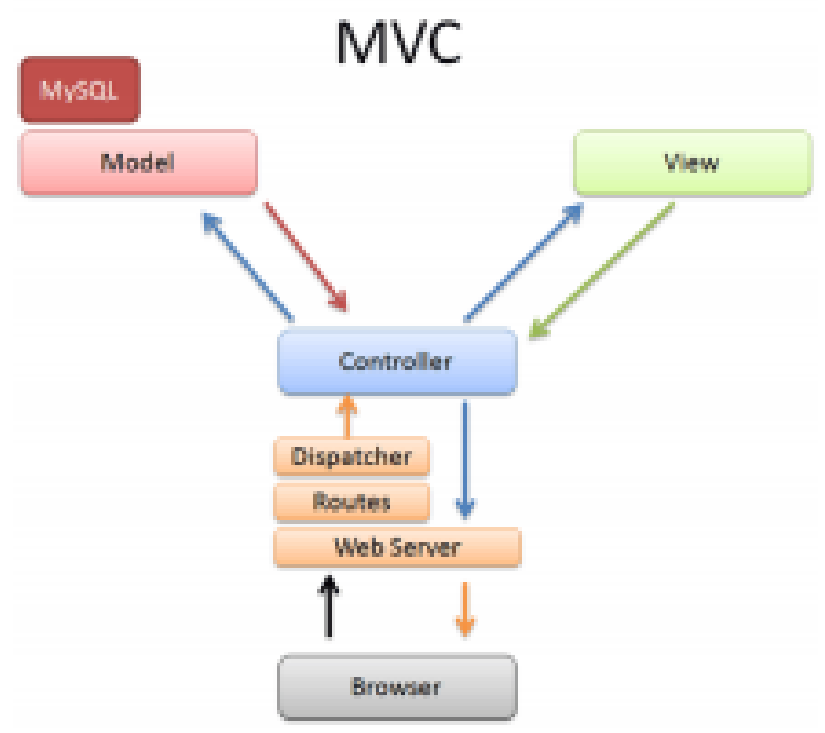

Gambar 1. Pattern MVC pada Codelgniter

\section{Metode}

Purnomo dan Zacharlas (2005) menyatakan prototype adalah sebuah proses yang memungkinkan pengembang dapat mencipta model perangkat lunak yang akan dibuat. Model ini dapat berbentuk prototipe dokumen, kerja atau program. Prototipe dokumen menggambarkan interaksi manusia- mesin sedemikian rupa sehingga costumer memahami pemakaian dan fungsi perangkat lunak tersebut. Prototipe kerja adalah implementasi sebagian dari fungsi perangkat lunak. Sedangkan prototipe program adalah implementasi semua fungsi program tetapi dengan antarmuka yang sederhana. Tahapan pada metode prototipe terdiri dari 
Pengumpul Kebutuhan, Desain Cepat, Pembentukan Prototype, Evaluasi dan Perbaikan dan Rekayasa Produk.

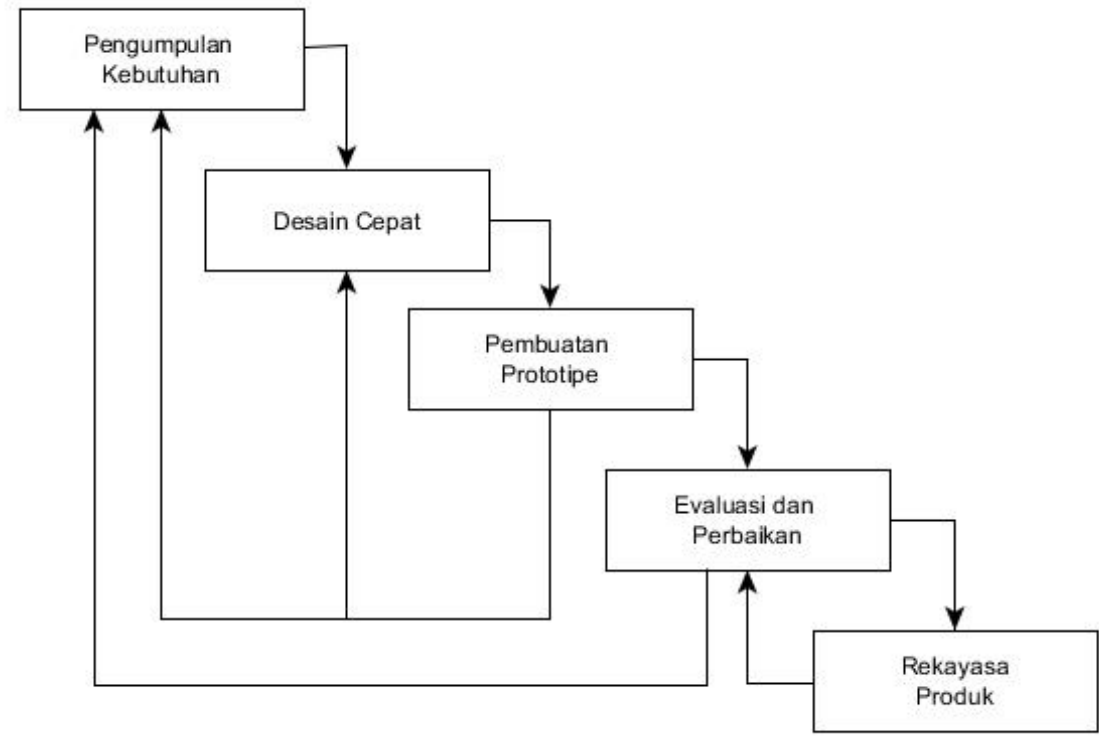

Gambar 2. Model Prototype (Purnomo dan Zacharlas, 2005)

\section{Hasil dan Pembahasan}

Hasil

\section{Pengumpulan Kebutuhan}

Dari hasil pengumpulan kebutuhan dengan melakukan wawancara, studi pustaka dan observasi maka diperoleh untuk mengusulkan kebutuhan aplikasi /sistem baru terdapat dua jenis kebutuhan untuk menghasilkan sistem yang baik, yaitu kebutuhan fungsional dan kebutuhan nonfungsional.

A. Kebutuhan Fungsional

Dalam sistem informasi manajemen surat keputusan mempunyai beberapa entitas user yang terdiri dari Pimpinan dalam hal ini (Dekan, Wakil Dekan, Ketua Jurusan, Ketua Program Studi, Kepala Bagian, Kepala Sub Bagian) dan Admin Jurusan. Masing-masing user memiliki kebutuhan fungsional sebagai berikut :

1. Admin Jurusan dapat mengusulkan pembuatan surat keputusan atas pengetahuan ketua jurusan. Admin jurusan juga bisa memantau/memonitor proses surat keputusan yang telah diusulkan. Sebagai pengelola sistem, admin dapat melakukan import data menggunakan web- service dari database SIAT diantaranya data dosen, data mahasiswa, data tahun akademik.

2. User ketua jurusan dan ketua program studi dapat memantau/memonitor surat keputusan yang telah diusulkan sebelumnya oleh admin jurusan. Untuk ketua jurusan, memilik akses untuk melakukan verifikasi dan menolak surat permohonan pembuatan surat keputusan yang diusulkan oleh admin jurusan. 
3. User sub bagian umum dan perlengkapan dapat menerima surat masuk berupa surat permohonan pembuatan surat keputusan yang diusulkan oleh admin jurusan. User dapat melakukan verifikasi dan menolak surat permohonan pembuatan surat keputusan. User akan menginput nomor agenda dan sifat surat jika surat permohonan telah diverifikasi.

4. User dekan dapat menerima surat masuk yang telah diverifikasi sebelumnya oleh sub bagian umum dan perlengkapan. User dapat melakukan disposisi terhadap surat permohonan tersebut. User dekan juga akan mendapatkan laporan berupa pemberitahuan jika ada surat keputusan yang perlu ditanda tangani.

5. User wakil dekan akan melakukan disposisi surat dari dekan. User juga dapat melakukan verifikasi dan menolak surat keputusan yang diusulkan oleh sub bagian pendidikan dan pengajaran, sub bagian keuangan dan sub bagian kemahasiswaan.

6. User kepala bagian akan melakukan disposisi surat dari wakil dekan.

7. User sub bagian pendidikan dan pengajaran, sub bagian keuangan, sub bagian kemahasiswaan akan membuat surat keputusan. Surat keputusan dibuat sesuai dengan surat permohonan pembuatan surat keputusan yang diusulkan oleh jurusan maupun membuat surat keputusan sesuai periode tahun akademik.

B. Kebutuhan Non-Fungsional

1. Sistem ini dapat berjalan di semua Sistem Operasi yang mendukung web browser.

2. Karena sistem yang dibangun berbasis web maka sistem ini membutuhkan aplikasi berupa web browser, Google Chrome, Mozilla Firefoc, Opera Mini dan sejenisnya.

3. Spesifikasi komputer minimum, Processor Intel Pentium 4 dan memori RAM minimal 512 Megabyte.

\section{Desain Cepat}

Pada tahap ini peneliti merumuskan desain Sistem Informasi Manajemen Surat Keputusan secara umum yang dapat dipahami oleh pengguna. Sistem ini mempunyai beberapa entitas pengguna terdiri dari, dekan, wakil dekan, kepala bagian dan kepala sub bagian yang akan melakukan disposisi dan verifikasi surat keputusan, admin jurusan melakukan pengusulan pembuatan surat keputusan dengan membuat surat permohonan pembuatan surat keputusan yang kemudian akan diverifikasi oleh ketua jurusan dan kepala sub bagian umum dan perlengkapan. 


\section{Pembuatan Prototipe}

Setelah melakukan analisis terhadap data dan informasi yang terlibat dalam proses sistem, penulis melakukan perancangan diagram konteks, relasi tabel database dan antarmuka aplikasi.

\section{Diagram Konteks}

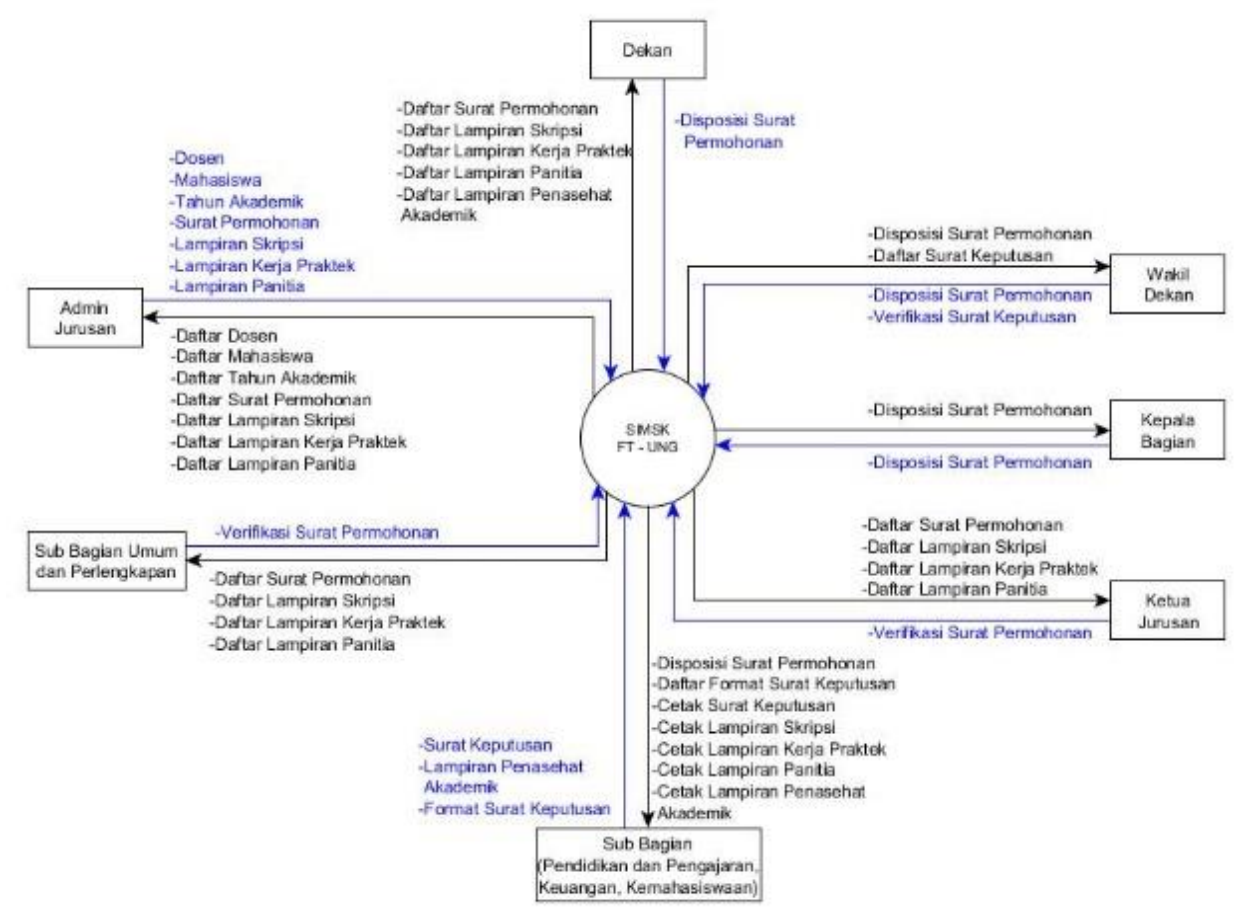

Gambar 3. Diagram Konteks

Gambar 3 menjelaskan masukkan data dosen, mahasiswa, tahun akademik, surat permohonan, lampiran skripsi, kerja praktek dan panitia dilakukan oleh admin jurusan serta lampiran penasehat akademik dilakukan oleh sub bagian pendidikan dan pengajaran. Untuk pembuatan surat keputusan dan format surat keputusan dilakukan oleh sub bagian (pendidikan dan pengajaran, keuangan, kemahasiswaan). Untuk proses pada sistem yang terdiri dari verifikasi surat dan disposisi surat dilakukan oleh dekan, wakil dekan, kepala bagian, sub bagian umum dan perlengkapan dan ketua jurusan. Dan untuk keluaran dari sistem terdiri dari daftar dosen, mahasiswa dan tahun akademik akan ditampilkan pada admin jurusan. Keluaran pada sistem yang akan ditampilkan pada sub bagian (pendidikan dan pengajaran, keuangan, kemahasiswaan) berupa daftar format surat keputusan dan user dapat mencetak surat keputusan, lampiran skripsi, kerja praktek, panitia dan penasehat akademik. 


\section{Relasi Tabel Database}

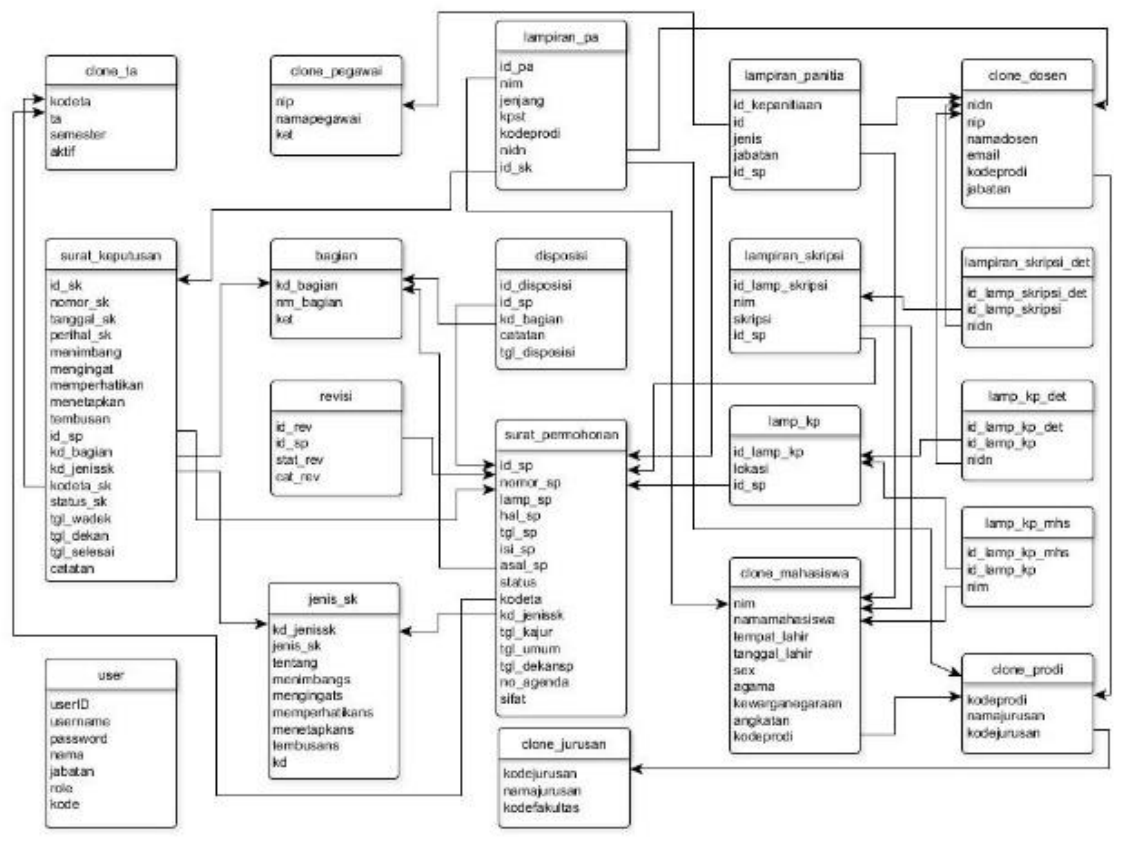

Gambar 4. Relasi Tabel Database

Gambar 4 adalah relasi tabel database sistem yang terdiri dari 20 tabel diantaranya tabel bagian, clone_dosen, clone_jurusan, clone_mahasiswa, clone_pegawai, clone_prodi, clone_ta, disposisi, jenis_sk, lampiran_pa, lampiran_panitia, lampiran_skripsi, lampiran_skripsi_det, lamp_kp, lamp_kp_mhs, lamp_kp_det, revisi, surat_keputusan, surat_permohonan, user.

\section{Rancangan Antarmuka}

Untuk mempermudah penulis melakukan rancangan antarmuka aplikasi. Adapun beberapa rancangan dari sistem ini yaitu sebagai berikut.

1. Rancangan Halaman Utama Semua User

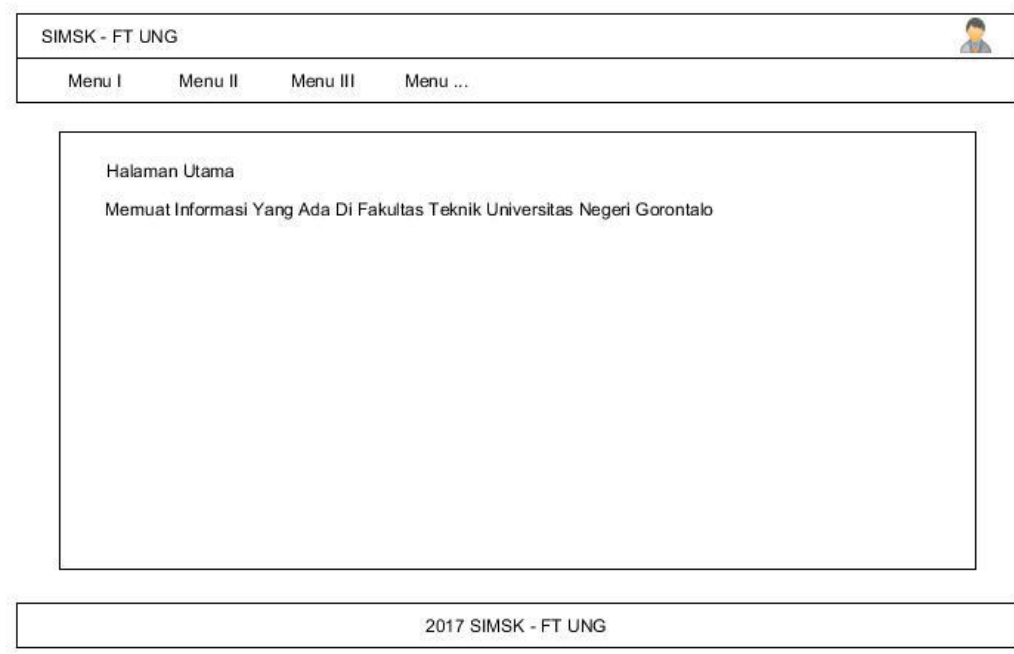

Gambar 5. Rancangan Halaman Semua User 
2. Rancangan Halaman Informasi Surat

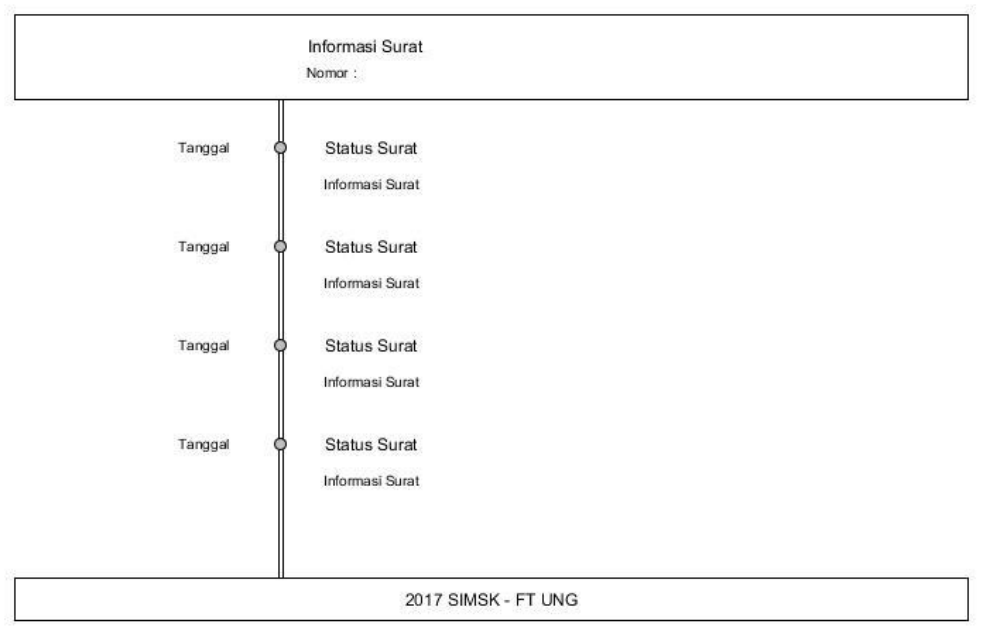

Gambar 6. Rancangan Informasi Surat

\section{Evaluasi dan Perbaikan}

Evaluasi yang dilakukan berupa pengujian aplikasi menggunakan metode blackbox. Proses pengujian ini dilakukan untuk membuktikan apakah sistem dapat memproses masukkan dan menghasilkan keluaran yang diharapkan.

Tabel 1. Pengujian Black Box

\begin{tabular}{llll}
\hline Masukkan / Aksi & \multicolumn{1}{c}{$\begin{array}{c}\text { Hasil yang } \\
\text { diharapkan }\end{array}$} & $\begin{array}{l}\text { Hasil yang } \\
\text { ditampilkan }\end{array}$ & Kesimpulan \\
\hline Masuk ke aplikasi & $\begin{array}{l}\text { Memproses } \\
\text { masukkan } \\
\text { username, } \\
\text { password dan role. }\end{array}$ & $\begin{array}{l}\text { Memproses } \\
\text { masukkan } \\
\text { username, } \\
\text { password dan } \\
\text { role. }\end{array}$ & Sesuai \\
Membuat Surat & $\begin{array}{l}\text { Surat keputusan } \\
\text { dapat disimpan }\end{array}$ & $\begin{array}{l}\text { Surat keputusan } \\
\text { berhasil disimpan }\end{array}$ & Sesuai \\
keputusan & $\begin{array}{l}\text { Memproses } \\
\text { keputusan }\end{array}$ & $\begin{array}{l}\text { Berhasil } \\
\text { melakukan }\end{array}$ & Sesuai \\
Menampilkan & $\begin{array}{l}\text { keputusan } \\
\text { Informasi surat } \\
\text { informasi surat }\end{array}$ & $\begin{array}{l}\text { verifikasi } \\
\text { Daftar informasi }\end{array}$ & Sesuai \\
$\begin{array}{l}\text { Cetak surat } \\
\text { keputusan }\end{array}$ & $\begin{array}{l}\text { Surat keputusan } \\
\text { dapat dicetak }\end{array}$ & $\begin{array}{l}\text { Cetak surat } \\
\text { keputusan }\end{array}$ & Sesuai \\
\hline
\end{tabular}




\section{Rekayasa Produk}

Pada tahap ini penulis melakukan pembuatan aplikasi menggunakan bahasa pemrograman PHP dan penyimpanan MySQL mengacuh pada tahap pembuatan prototipe.

1. Tampilan Halaman Login

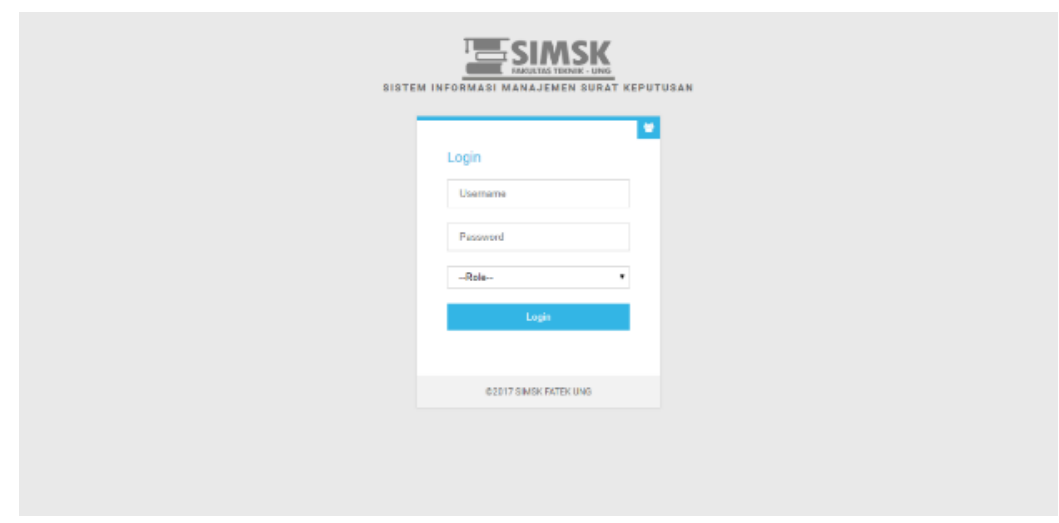

Gambar 7. Halaman Login

Gambar 7 adalah halaman awal aplikasi ketika aplikasi SIMSK diakses oleh user. Halaman akan menampilakan form login dimana user harus mengisi username, password dan memilih role atau bagian. Role atau bagian terdiri dari Dekan, Wakil Dekan, Ketua Jurusan, Kepala Bagian, Operator Sub Bagian dan Operator Jurusan.

2. Tampilan Halaman Utama Semua User

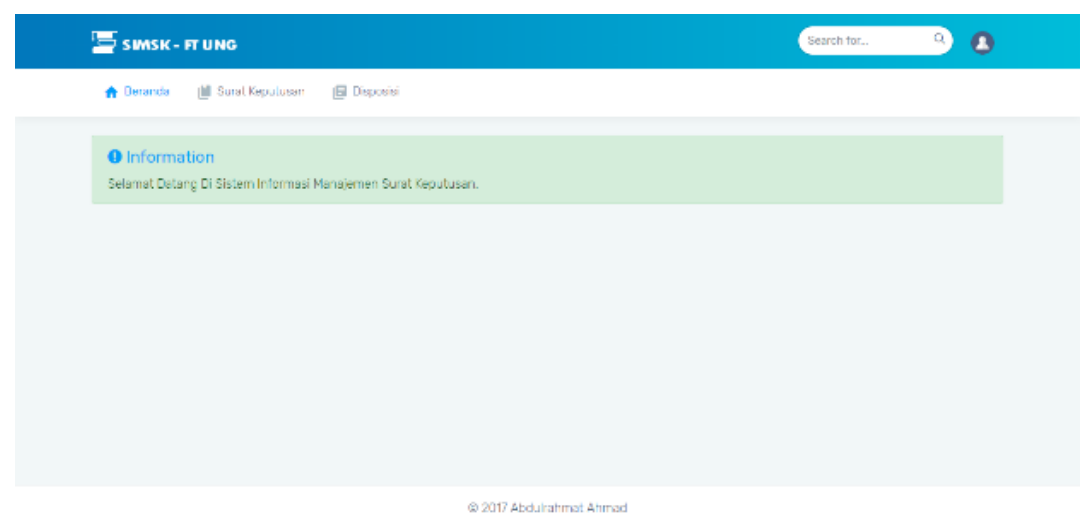

Gambar 8. Halaman Utama Semua User login.

Gambar 8 adalah halaman utama pada setiap user yang berhasil melakukan 
3. Tampilan Halaman Surat Keputusan

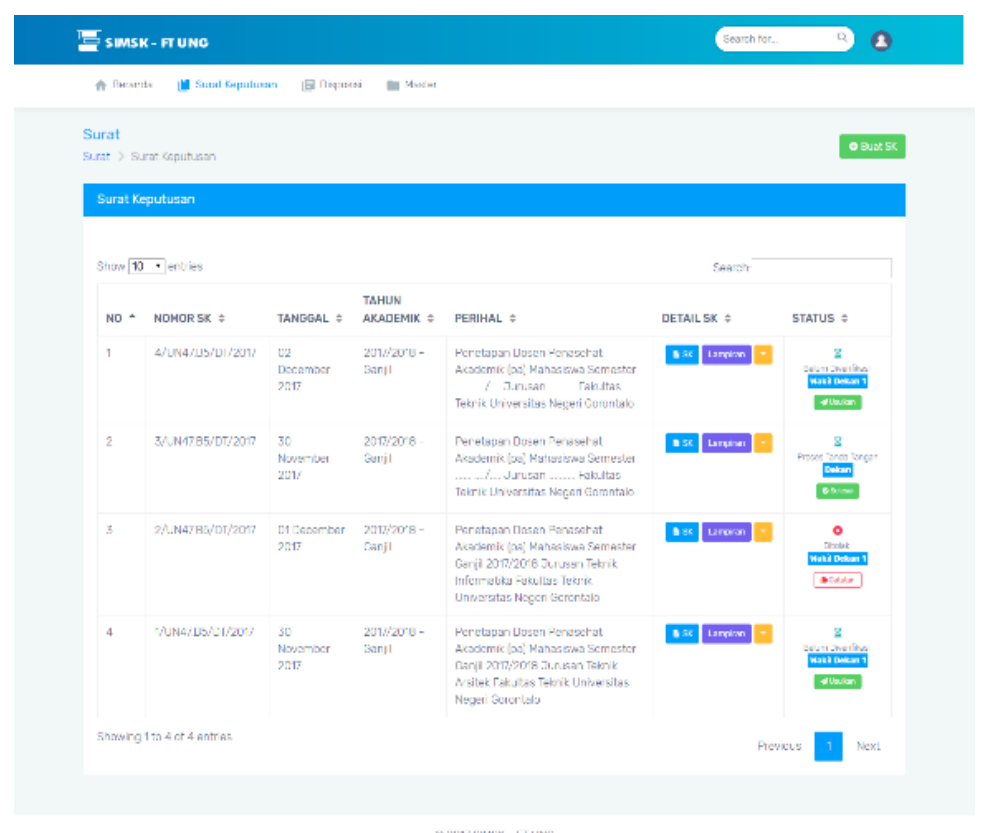

Gambar 9. Halaman Surat Keputusan

Gambar 9 adalah halaman utama sistem yang hanya bisa diakses oleh operator sub bagian pendidikan dan pengajaran, keuangan dan kemahasiswaan. Dihalaman ini ditampilkan daftar surat keputusan yang telah dibuat. Surat keputusan yang dibuat kemudian diusulkan untuk diverifikasi oleh wakil dekan. Kolom status akan menampilkan status surat apakah diverifikasi atau ditolak. User juga dapat melihat detail surat dan lampiran. Surat keputusan bisa dicetak jika surat telah diverifikasi oleh wakil dekan. 
4. Tampilan Halaman Buat Surat Keputusan

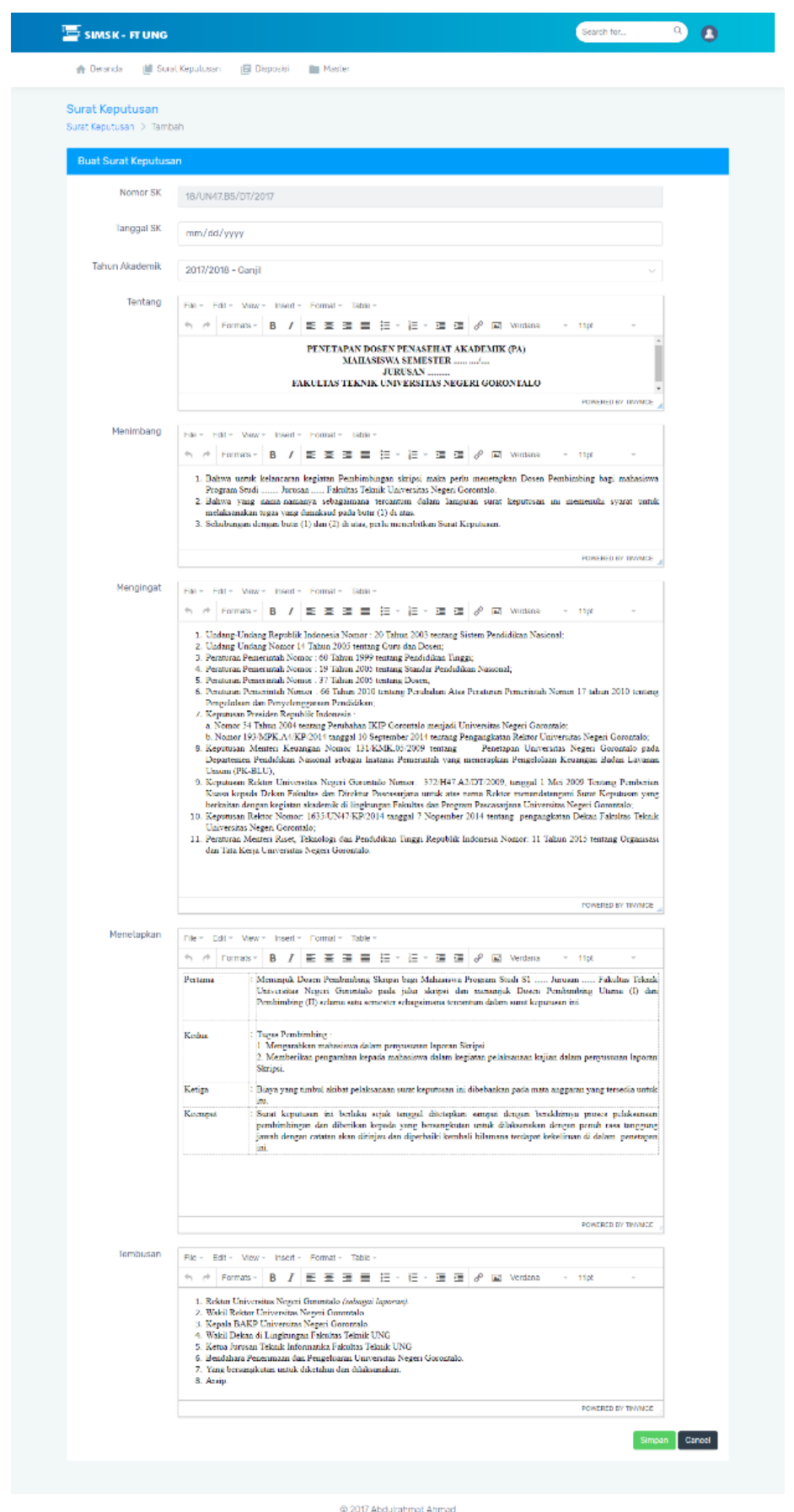

Gambar 10. Halaman Buat Surat Keputusan

Gambar 10 adalah halaman menampilkan form pembuatan surat keputusan. Nomor surat keputusan telah otomatis di generate oleh sistem sesuai dengan format nomor surat keputusan yang ada sehingga user tidak lagi memasukkan nomor surat keputusan. Begitupun dengan konsideran yang akan otomatis terisi sesuai dengan jenis surat keputusan yang dipilih. Tahun akademik juga akan menampilkan tahun akademik yang sedang aktif. 
5. Tampilan Halaman Cetak Surat Keputusan

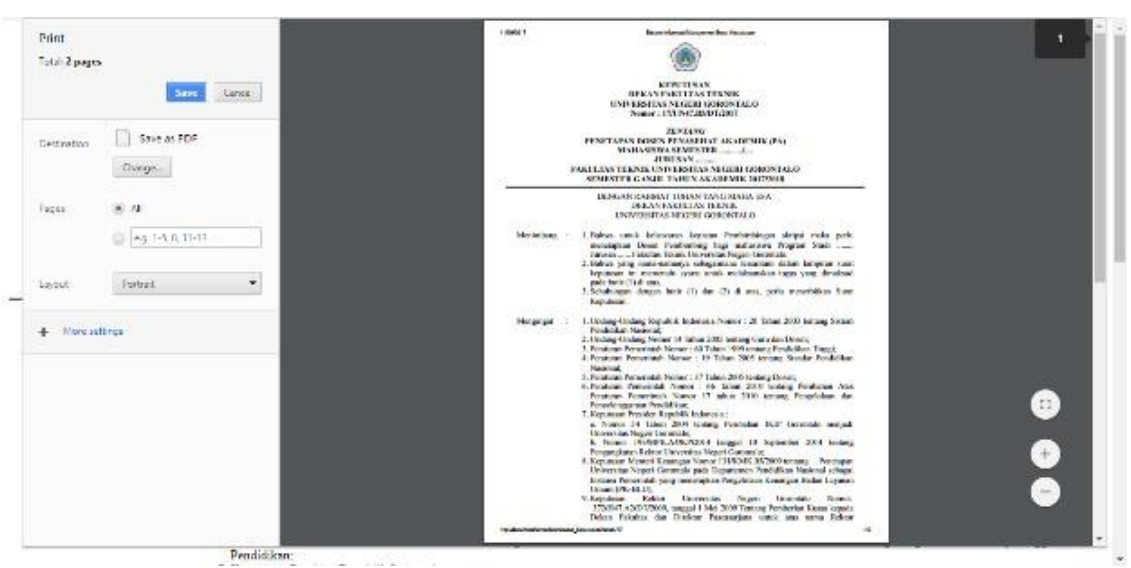

Gambar 11. Halaman Cetak Surat Keputusan

Gambar 11 adalah halaman cetak surat keputusan yang telah dibuat sebelumnya dan sudah diverifikasi oleh wakil dekan. Surat keputusan yang akan dicetak sudah disesuaikan seperti yang telah diinput sebelumnya.

6. Tampilan Halaman Informasi Surat

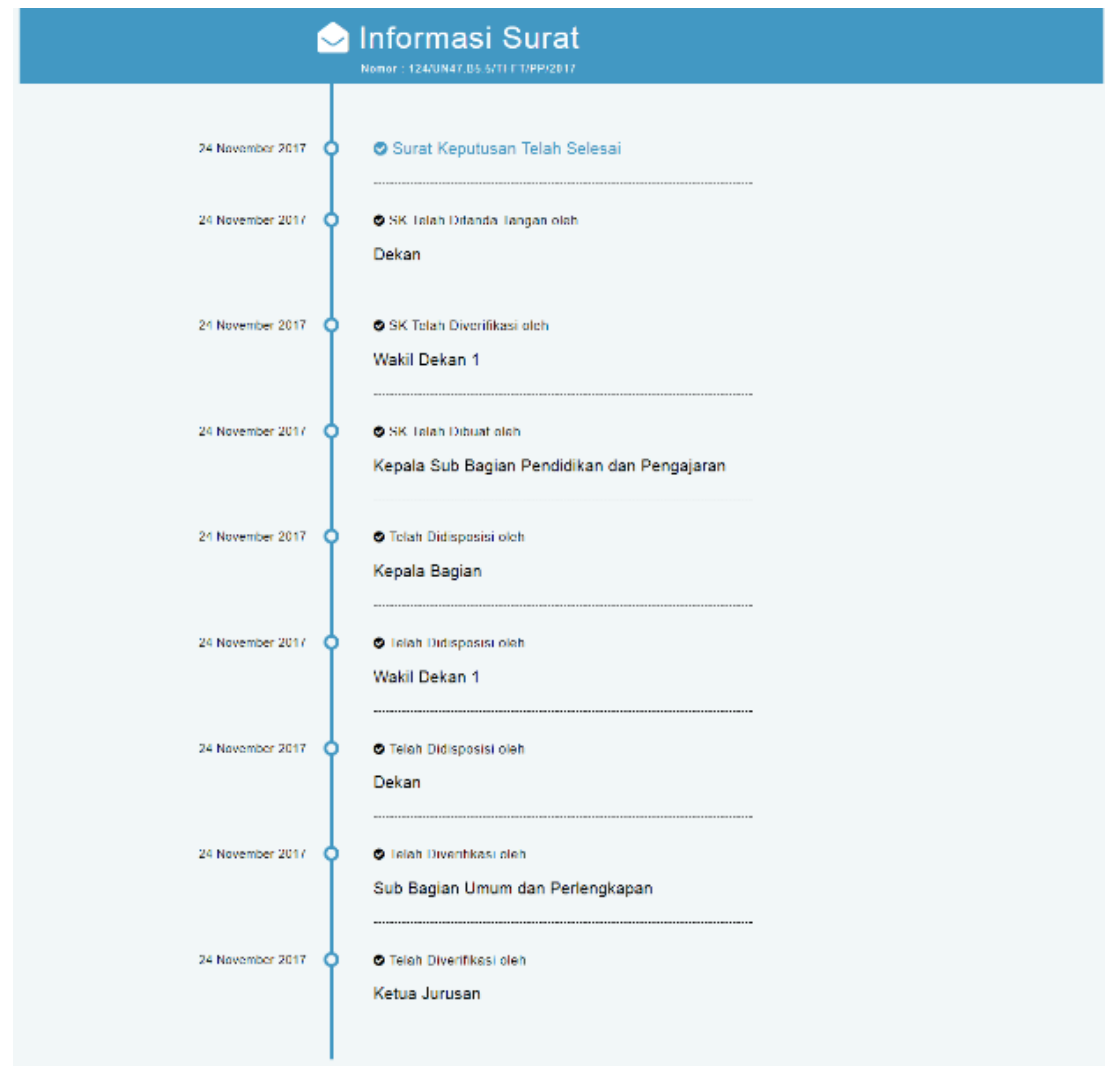

Gambar 12. Halaman Informasi Surat

Gambar 12 adalah halaman detail informasi ketika user menekan tombol informasi dihalaman informasi surat. Halaman ini menampilkan posisi surat yang diusulkan telah sampai pada proses apa. 


\section{Pembahasan}

Berdasarkan hasil tahapan yang telah dilakukan, penelitian ini menghasilkan Sistem informasi manajemen surat keputusan berbasis web. Sistem ini diaplikasikan dengan menggunakan bahasa pemrograman PHP framework Codeigniter dan menggunakan teknologi web service sebagai pertukaran data. Sistem ini dibuat untuk mengoptimalkan pengelolaan surat keputusan yang ada dilingkungan Fakultas Teknik Universitas Negeri Gorontalo.

Pengoptimalan pengelolaan surat keputusan yang ada yaitu dengan mengatasi beberapa kendala dan masalah yang sering terjadi. Dengan adanya sistem ini, kendala yang terjadi seperti proses pembuatan surat keputusan yang memakan waktu lama dapat diatasi dengan mudahnya user dalam membuat surat keputusan. Disistem ini nomor surat keputusan akan otomatis di generate oleh sistem sesuai dengan format nomor surat keputusan yang ada. Kemudahan lainnya yaitu user tidak perlu memasukkan semua konsideran surat keputusan, karena disistem ini konsideran akan terisi sesuai dengan jenis surat keputusan yang akan dibuat.

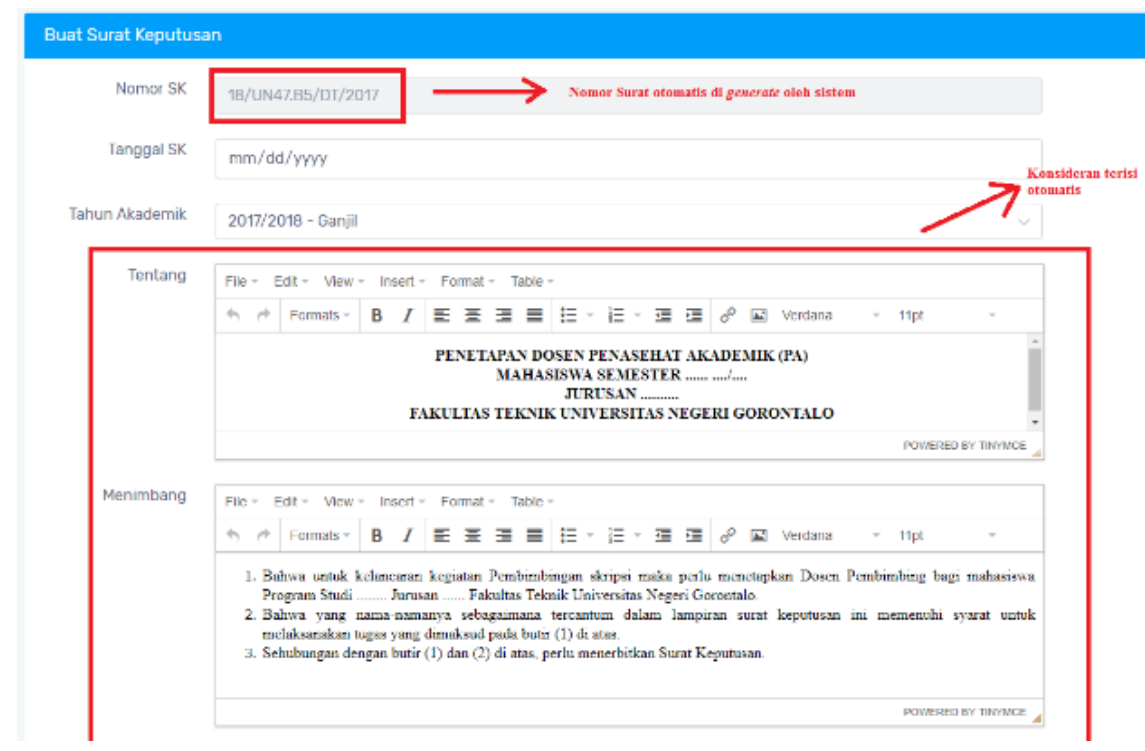

Gambar 13. Nomor Surat Keputusan dan Konsideran otomatis

Kendala lainnya yaitu proses pengusulan surat keputusan yang lambat dan pendistribusian surat tidak sampai kepada yang mengusulkan dapat diatasi oleh sistem dengan melihat informasi surat yang diusulkan telah sampai pada proses apa. 


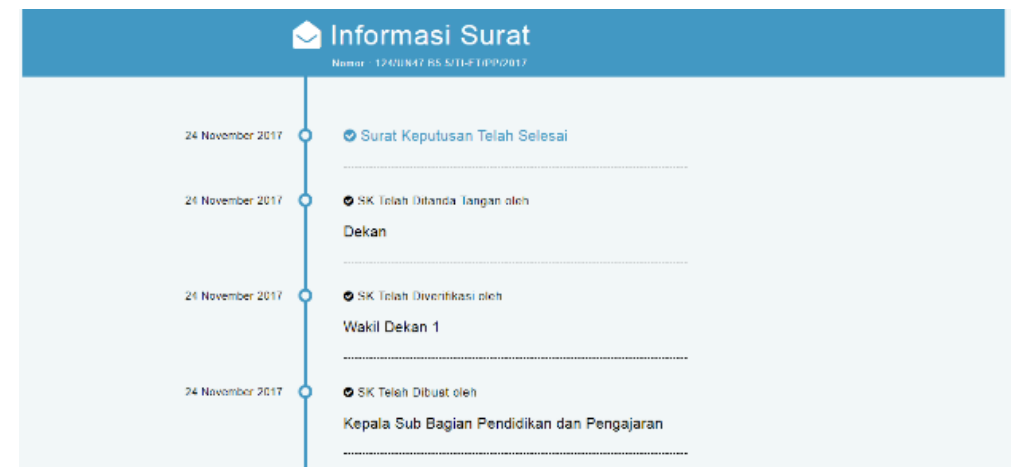

Gambar 14. Informasi Surat

\section{Kesimpulan dan Saran}

Berdasarkan hasil penelitian dan pembahasan yang telah diuraikan maka dapat disimpulkan bahwa :

1. Pada penelitian ini merancang sebuah sistem informasi yang meliputi manajemen surat keputusan yang ada di Fakultas Teknik Universitas Negeri Gorontalo. Sistem Informasi Manajemen Surat Keputusan merupakan sistem yang diaplikasikan menggunakan bahasa pemrograman PHP framework Codeigniter dan penyimpanan MySQL serta menggunakan teknologi web service untuk pertukaran data.

2. Sistem Informasi Menajemen Surat Keputusan ini dapat mengolah nomor surat keputusan secara otomatis sesuai dengan format nomor surat keputusan yang ada di Fakultas Teknik Universitas Negeri Gorontalo.

3. Sistem Informasi Manajemen Surat Keputusan ini dapat memonitoring surat sehingga dari awal pengusulan surat, proses pembuatan surat, sampai surat selesai dibuat akan terlihat jelas informasinya.

4. Sistem Informasi Manajemen Surat Keputusan ini dapat mengoptimalkan pengelolaan surat keputusan yang ada di Fakultas Teknik Universitas Negeri Gorontalo.

Setelah membangun sistem, didapatkan beberapa saran untuk upaya pengembangan sistem selanjutnya, yaitu :

1. Penggunaan posisi kertas portrait dan landscape secara bersamaan agar digunakan secara otomatis sehingga user dapat mencetak surat dengan cepat.

2. Penggunaan teknologi tanda tangan online jika diperlukan.

3. Sistem lebih dinamis dalam pembuatan jenis surat keputusan baru beserta lampiran dengan memperhatikan desain database.

4. Sistem dapat diterapkan disemua jurusan yang ada di Universitas Negeri Gorontalo. 


\section{Daftar Pustaka}

Anggraini, D. 2008. Jurnal IImiah Pengembangan Sistem Informasi Tata Persuratan Menggunakan UML dan Natural Language Processing. Jurnal Informatika Komputer, Vol. 13, No. 3.

Deviana, H. 2007. Penerapan XML Web Service pada Sistem Distribusi Barang. Jurnal Generic, (Online), Volume 6, No. 2, (http://download. portalgaruda.org/article. php?article=122577\&val=5501, diakses 25 mei 2017).

Kusrini. 2007. Konsep dan Aplikasi Sistem Pendukung Keputusan. Yogyakarta : Andi Offset.

Purnomo, H., dan Zacharlas, T. 2005. Pengenalan Informatika Perspektif Teknik dan Lingkungan. Yogyakarta : Andi.

Tidwell, D. 2001. Web Service: The Web's next Revolution, (online), (http://www6.software.ibm.com/develo perworks/education/wsbasic/wsbasica4.pdf, di akses 29 mei 2017).

Wardana. 2012. Menjadi Master PHP dengan Framework Codelgniter. Jakarta : PT. Elex Media Komputindo. 